\title{
Article \\ Electrochemically Enhanced Deposition of Scale from Chosen Formation Waters from the Norwegian Continental Shelf
}

\author{
Benjamin Udo Emmel, Kamila Maria Gawel (D), Mohammad Hossain Bhuiyan (D), Malin Torsæter \\ and Laura Edvardsen *
}

Citation: Emmel, B.U.; Gawel, K.M.; Bhuiyan, M.H.; Torsæter, M.; Edvardsen, L. Electrochemically Enhanced Deposition of Scale from Chosen Formation Waters from the Norwegian Continental Shelf Energies 2022, 15, 542. https:// doi.org/10.3390/en15020542

Academic Editor: Rafael J. Bergillos

Received: 13 December 2021

Accepted: 11 January 2022

Published: 13 January 2022

Publisher's Note: MDPI stays neutral with regard to jurisdictional claims in published maps and institutional affiliations.

Copyright: (C) 2022 by the authors. Licensee MDPI, Basel, Switzerland. This article is an open access article distributed under the terms and conditions of the Creative Commons Attribution (CC BY) license (https:// creativecommons.org/licenses/by/ $4.0 /)$.
SINTEF Industry, 7465 Trondheim, Norway; BenjaminUdo.emmel@sintef.no (B.U.E.); Kamila.gawel@sintef.no (K.M.G.); Mohammad.bhuiyan@sintef.no (M.H.B.); Malin.Torsater@sintef.no (M.T.)

* Correspondence: Laura.edvardsen@sintef.no

Abstract: Reservoir formation waters typically contain scaling ions which can precipitate and form mineral deposits. Such mineral deposition can be accelerated electrochemically, whereby the application of potential between two electrodes results in oxygen reduction and water electrolysis. Both processes change the local $\mathrm{pH}$ near the electrodes and affect the surface deposition of $\mathrm{pH}$-sensitive minerals. In the context of the plugging and abandonment of wells, electrochemically enhanced deposition could offer a cost-effective alternative to the established methods that rely on setting cement plugs. In this paper, we tested the scale electro-deposition ability of six different formation waters from selected reservoirs along the Norwegian continental shelf using two experimental setups, one containing $\mathrm{CO}_{2}$ and one without $\mathrm{CO}_{2}$. As the electrochemical deposition of scaling minerals relies on local $\mathrm{pH}$ changes near the cathode, geochemical modelling was performed to predict oversaturation with respect to the different mineral phases at different $\mathrm{pH}$ values. In a $\mathrm{CO}_{2}$-free environment, the formation waters are mainly oversaturated with portlandite at $\mathrm{pH}>12$. When $\mathrm{CO}_{2}$ was introduced to the system, the formation waters were oversaturated with calcite. The presence of mineral phases was confirmed by powder X-ray diffraction (XRD) analyses of the mineral deposits obtained in the laboratory experiments. The geochemical-modelling results indicate several oversaturated Mg-bearing minerals (e.g., brucite, dolomite, aragonite) in the formation waters but these, according to XRD results, were absent in the deposits, which is likely due to the significant domination of calcium-scaling ions in the solution. The amount of deposit was found to be proportional to the concentration of calcium present in the formation waters. Formation waters with a high concentration of Ca ions and a high conductivity yielded more precipitate.

Keywords: mineral scale; well plugging; electro-deposition; formation water

\section{Introduction}

The exploration of the Earth's interior has been pursued by mankind for millennia: from drilling small wells to access fresh water, to making large well structures to extract energy. Regardless of the function of the well, the principle is the same: a well connects the surface with the subsurface [1]. Now, wells allow us to gather scientific data from deep inside the Earth, produce oil or gas, inject gases into reservoirs for long- or short-term storage, extract geothermal energy and bury nuclear waste and other contaminants.

All types of wells need to be permanently plugged and abandoned (P\&A) in the near future. If not, the well acts as a channel between the surface and the underground, allowing reservoir fluids to leak and therefore become potential threats to groundwater quality and onshore/offshore ecosystems [2]. The P\&A procedures typically involve the removal of long sections of steel pipes, placing a number of cement plugs in the wellbore and the restoration of annular barriers in the well [3-6]. These operations are huge cost drivers due to the need for expensive drilling rigs and equipment [6]. In the North Sea, up to $£ 3$ billion 
each year will be spent on decommissioning activities over the upcoming years, and 50\% of these costs are associated with P\&A operations [6].

The permanent plugging of a well aims to use methods and materials that can perpetually withstand downhole temperature, pressure and geochemical conditions [7]. However, placing cement plugs inside the wellbore is often not sufficient to prevent leakage after P\&A operations since leakage can occur in the annulus outside the casing [6]. This issue becomes particularly relevant for older wells, where the annular cement and the outer-casing cement may be mechanically degraded as a result of mechanical stresses imparted on the well-construction elements during well operations (e.g., production, injection, pressure testing etc).

In this study, a new approach towards a cheaper P\&A process was investigated, with the potential for limiting the use of rigs to remove pipes and pump cement. The concept exploits scale formation, which is a long standing problem for many industries [8,9]. Scale formation occurs due to the precipitation of mineral compounds that are present in water [10]. These precipitated minerals adhere to solid surfaces, causing deposits to form. In the oil and gas industry, unwanted scale formation can clog pipelines [11], as well as lead to equipment shutdown, and has been categorized as one of the most costly problems [12]. Scale formation also poses a risk for geothermal wells because hot geothermal fluids often contain large amounts of dissolved minerals [13]. Although mineral scale is highly undesirable when a well is operative, it can be an asset in the context of P\&A. By accelerating scale formation inside and outside well pipes, scale barriers can be formed to seal off leakage pathways.

To enhance scale formation, cathodic polarization of electroconductive surfaces can be utilized [14]. As the precipitation and dissolution of many scaling minerals (e.g., calcium carbonate) are affected by $\mathrm{pH}$, the local $\mathrm{pH}$ changes near the electrodes during water electrolysis can be utilized to control the scaling [15-17]. During water electrolysis, hydroxide ions are generated at the cathode; see reaction (1) [18].

$$
2 \mathrm{H}_{2} \mathrm{O}+2 \mathrm{e}^{-} \rightarrow \mathrm{H}_{2}+2 \mathrm{OH}^{-}
$$

The generation of hydroxide causes the local $\mathrm{pH}$ near the cathode to become alkaline, which will accelerate the deposition of some scaling minerals, e.g., calcium carbonate [16]. At the anode, the oxidation reaction occurs; see reaction (2). This causes the local $\mathrm{pH}$ near the anode to be acidic [18], which may inhibit the deposition of some scaling minerals [16,17].

$$
2 \mathrm{H}_{2} \mathrm{O} \rightarrow \mathrm{O}_{2}+4 \mathrm{H}^{+}+4 \mathrm{e}^{-}
$$

Edvardsen et al. [16] showed that cathodic polarization of a graphite surface significantly enhanced deposition of calcium carbonate. A strong correlation between the scaling rate and potential magnitude was found, where amount of precipitate increased with increasing polarization potential. A study on conductive epoxy/carbon nanofiber coatings showed that scale deposition was manipulated upon polarization [17]. Scale control was induced when the surface was polarized anodically, and the deposited layer was significantly reduced compared to no and cathodic polarization.

In this paper we studied the concept of electrochemically enhanced deposition from synthetic formation waters that are similar in composition to the Gyda, Ekofisk, Sleipner, Troll, and Statfjord fields and the Smeaheia fault block. The main objective was to (i) investigate the effect of formation-water composition on electrode scale deposition, (ii) to study the effect of $\mathrm{CO}_{2}$ on electrochemical scale precipitation and (iii) to discuss the results in the context of $\mathrm{P} \& \mathrm{~A}$ during $\mathrm{CO}_{2}$ storage.

The work is structured as follows. In Section 2 we present the methodology of the geochemical modelling and experimental setup. In Section 3 the modelling and laboratory results are presented and described. In Section 4 we discuss the difference between the modelling and experimental results, and present implications for the possible application of mineral electro-deposition in well plugging. The conclusion is given in Section 5. 


\section{Materials and Methods}

Electrochemical experiments were conducted using formation-water compositions from the Gyda, Ekofisk, Sleipner, Troll and Statfjord oil and gas fields, and the Smeaheia fault block. The fields were chosen because of their different P\&A status at the Norwegian continental shelf (NCS). In 1990, Gyda was known as the deepest, lowest-permeability oil field in the North Sea with high reservoir temperatures and a complex formation-water geochemistry [19]. This field is currently under decommission. The Ekofisk field is one of the oldest Norwegian fields still producing oil. However, Ekofisk is suffering from high rates of sea-floor subsidence and was the epicentre of a moderate seismic event in 2001 [20]. Reservoir compaction and surface subsidence have previously led to well-casing deformation at the Ekofisk field [21], and most probably also diminished the well integrity. At the Sleipner field $\mathrm{CO}_{2}$ storage is ongoing [22], while the Smeaheia fault block has been under evaluation for $\mathrm{CO}_{2}$ storage [23]. The Statfjord field was the largest oil discovery in the North Sea and is reaching its end of production. From this field many geochemical analyses have been published [24].

\subsection{Geochemical Modelling}

The mineral dissolution and precipitation at different $\mathrm{pH}$ values under laboratory conditions were modelled using the PHREEQC (USGS, Reston, US) software applying the wateq4f.dat thermodynamic data file [25]. The thermodynamic data file is based on WATEQ4F [26] and contains more elements, aqueous species and minerals than the phreeqc.dat data file [27]. PHREEQC is a general-purpose geochemical software based on the law of mass action and can be applied to most hydrogeochemical environments [28].

For the different formation waters with compositions given in Table 1, the initial $\mathrm{pH}$ was varied, and the saturation index (SI) was modelled for different mineral phases. The $\mathrm{SI}$ is defined as the ratio between the ion-activity product in non-equilibrium and the thermodynamic solubility product. A solution is oversaturated if the SI is larger than 0 , indicating the specific mineral phase might precipitate. The solution is undersaturated if the SI is less than 0 , and the ions necessary to build mineral phases stay in solution (e.g., Metoki et al.) [29]. For simulations that were run with additional $\mathrm{CO}_{2}$, the formation waters were modelled in an equilibrium with $\mathrm{CO}_{2}$ gas with a target $\mathrm{SI}$ of 1 , to mimic the dynamic laboratory experiments with static models.

Table 1. Compositions of the different formation waters [24,30]. The compounds (in grams) were mixed with deionized water to make up a total of $1 \mathrm{~L}$ solution.

\begin{tabular}{|c|c|c|c|c|c|c|}
\hline Component & Gyda & Smeaheia & Ekofisk & Sleipner & Troll & Statfjord \\
\hline $\mathrm{NaCl}$ & 135.17 & 43.95 & 61.63 & 84.39 & 38.97 & 21.35 \\
\hline $\mathrm{KCl}$ & 8.54 & 19.92 & 0.35 & 2.18 & 0.54 & 0.29 \\
\hline $\mathrm{MgCl}_{2} \cdot 6 \mathrm{H}_{2} \mathrm{O}$ & 17.67 & 6.13 & 4.24 & 7.39 & 2.99 & 0.47 \\
\hline $\mathrm{CaCl}_{2} \cdot 2 \mathrm{H}_{2} \mathrm{O}$ & 97.24 & 15.63 & 17.75 & 13.41 & 5.69 & 1.78 \\
\hline $\mathrm{NaHCO}_{3}$ & 0.60 & 0 & 0.52 & 0.56 & 0.79 & 0.95 \\
\hline $\mathrm{Na}_{2} \mathrm{SO}_{4}$ & 2.90 & 0 & 0.03 & 0.01 & 0.13 & 0.01 \\
\hline $\mathrm{FeCl}_{3}$ & 0.41 & 0 & 0 & 0 & 0 & 0 \\
\hline $\mathrm{LiCl}$ & 0 & 0.02 & 0 & 0 & 0 & 0 \\
\hline
\end{tabular}

The most relevant reaction equations, stability constants and enthalpies used from the wateq4f.dat file are given in the supplementary data (Table S1).

\subsection{Electrochemical Experimental Setup}

The electrochemical deposition of scale was induced by applying a potential between the working electrode (cathode) and the counter electrode (anode) (see Figure 1). A GW Laboratory DC Power Supply (model GPS-3030) was used as a power source. A Fluke 12 Multimeter was used to measure the applied voltage. The electrodes were graphite 
hollow cylinders with a hole diameter of $4 \mathrm{~mm}$, an outer diameter of $10 \mathrm{~mm}$ and a length of $30 \mathrm{~mm}$.

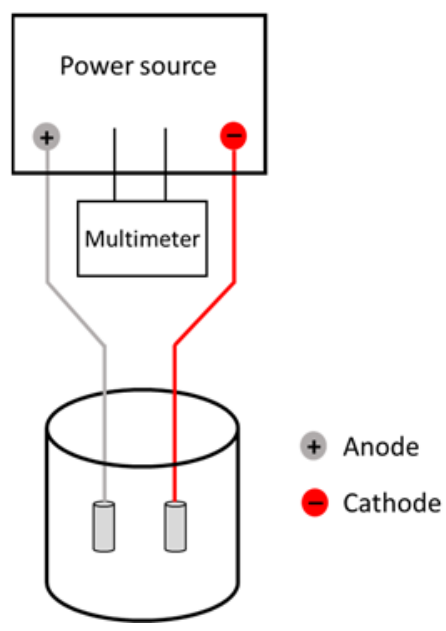

Figure 1. Illustration of the two-electrode experimental setup.

To control the electrode surface area in contact with the formation water, the top part $(15 \mathrm{~mm})$ of the graphite electrodes was wrapped with an electrically isolating tape. The cathode and anode were placed in the formation water $(200 \mathrm{~mL})$ approximately $4 \mathrm{~cm}$ apart from each other, and the potential was set to $5 \mathrm{~V}$. The formation water was made following the description given in Section 2.3. Experiments were conducted at $22.3-22.6{ }^{\circ} \mathrm{C}$ and the electrodes were polarized for $30 \mathrm{~min}$. After polarization, the electrodes were washed with deionized water to remove excess brine and to prevent excessive crystallization of the remaining salt during the drying process. The weight of the graphite tubes was measured before and after the samples had dried completely, with a Mettler AT250 (Mettler-Toledo $\mathrm{GmBH}$, Greifensee, Switzerland) precision weight. Photographs of the cathodes document the visual degree of scaling. First, the six different formation waters were tested without any add-ons (Exp1). The same experimental setup was used to test the effect of $\mathrm{CO}_{2}$ on the deposition of scaling minerals (Exp2). $\mathrm{A} \mathrm{CO}_{2}$ distributor was placed between the electrodes and a constant flow of $\mathrm{CO}_{2}$ at a rate of $1.25 \mathrm{~mL} / \mathrm{min}$ was injected into the formation water during the experiment.

\subsection{Formation-Water Solutions}

The formation-water compositions of the Gyda, Smeaheia, Ekofisk, Sleipner, Troll, Sleipner and Statfjord field reservoirs are presented in Table 1. The compounds were mixed with deionized water to make up a total of 1 L solution. The compositions of Gyda, Ekofisk, Troll and Statfjord were calculated as averages from individual formation-water samples reported by Warren et al. [24]. For the Smeaheia and Sleipner formation waters, only one composition was available [30]. All formation-water compositions contained barium (Ba), bromide (Br) and strontium (Sr) ions, except for Sleipner where no Br was present. These were neglected in the experiments due to laboratory health and safety regulations, and therefore also neglected in the presentation of the simulation results.

\subsection{Powder X-ray Diffraction (XRD)}

Powder X-ray diffraction (XRD) was used to determine the mineralogical composition of the precipitated deposit. A Bruker D8 Advance (Bruker Scientific Instruments, Billerica, US) (with DAVINCI design) instrument at the Material and Chemistry Department, NTNU was used. The mineral deposits were removed from the electrode surfaces, dried, and ground into silt-sized particles. The sample was dispersed on the surface of an Si-sample holder using XRD transparent grease. The XRD pattern was measured between $2-55^{\circ}(2 \theta)$ using a Cu-K $\alpha$ source (giving X-rays of wavelength 1.54 $\AA$ ) and a LYNXEYE_XE (Bruker 
Scientific Instruments, Billerica, US) (1D mode) detector for 45 min of exposure time. The XRD pattern was analysed using the DIFFRAC.EVA v.5.2 software (Bruker Scientific Instruments, Billerica, US) and the crystalline phases indicated by the pattern were defined.

\section{Results}

\subsection{Modelling Results}

Numerical simulations were run for all formation waters at laboratory conditions, both without and with $\mathrm{CO}_{2}$. Modelling results for different mineral phases are presented in Figures 2 and 3. Only the mineral phases that had an SI greater than zero at any $\mathrm{pH}$ value are shown in the figures.
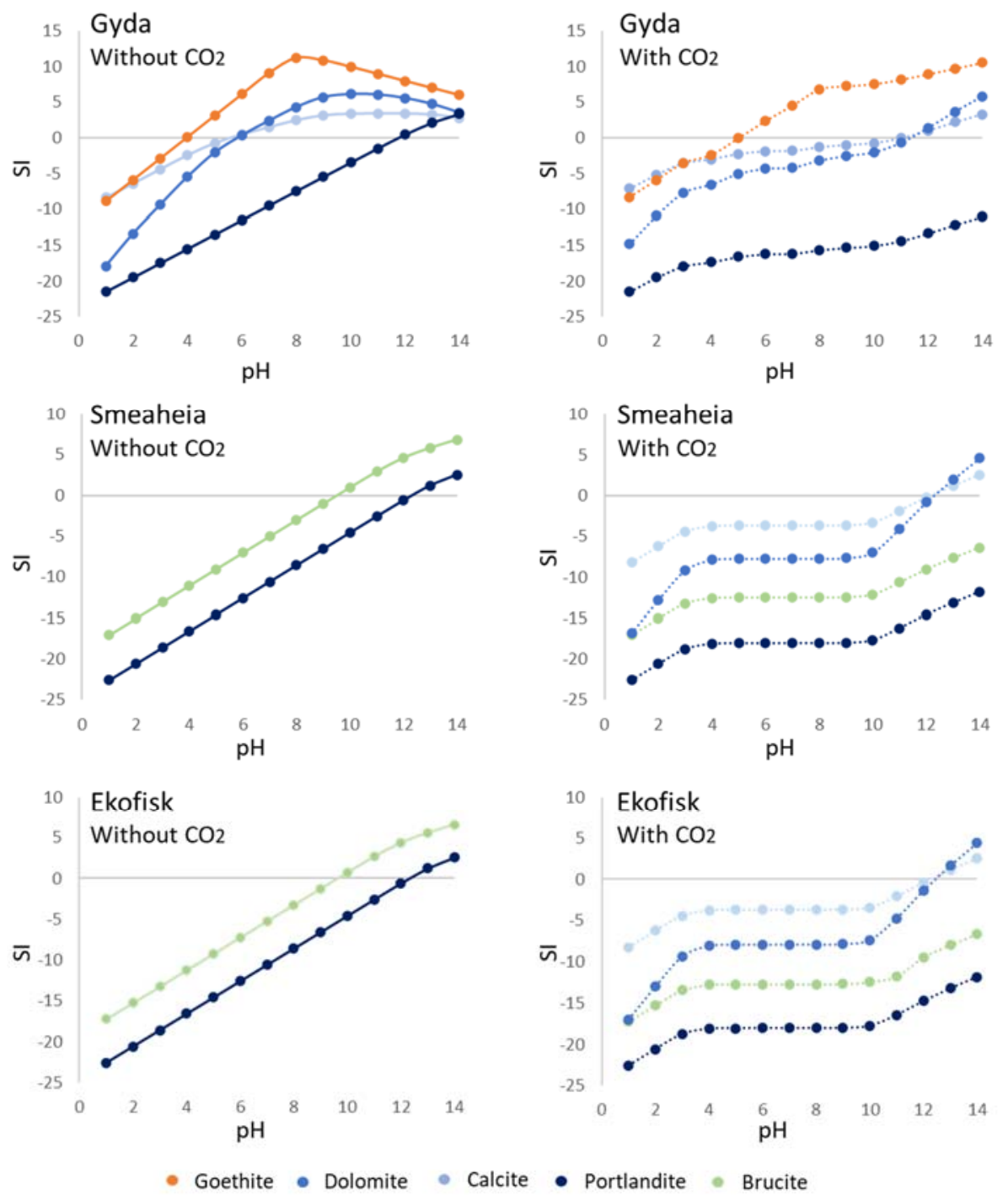

Figure 2. Modelled saturation indices (SI) for Gyda, Smeaheia and Ekofisk formation waters at $23^{\circ} \mathrm{C}$ and $1 \mathrm{~atm}$ for different $\mathrm{pH}$ values, without (left) and with (right) additional $\mathrm{CO}_{2}$. 

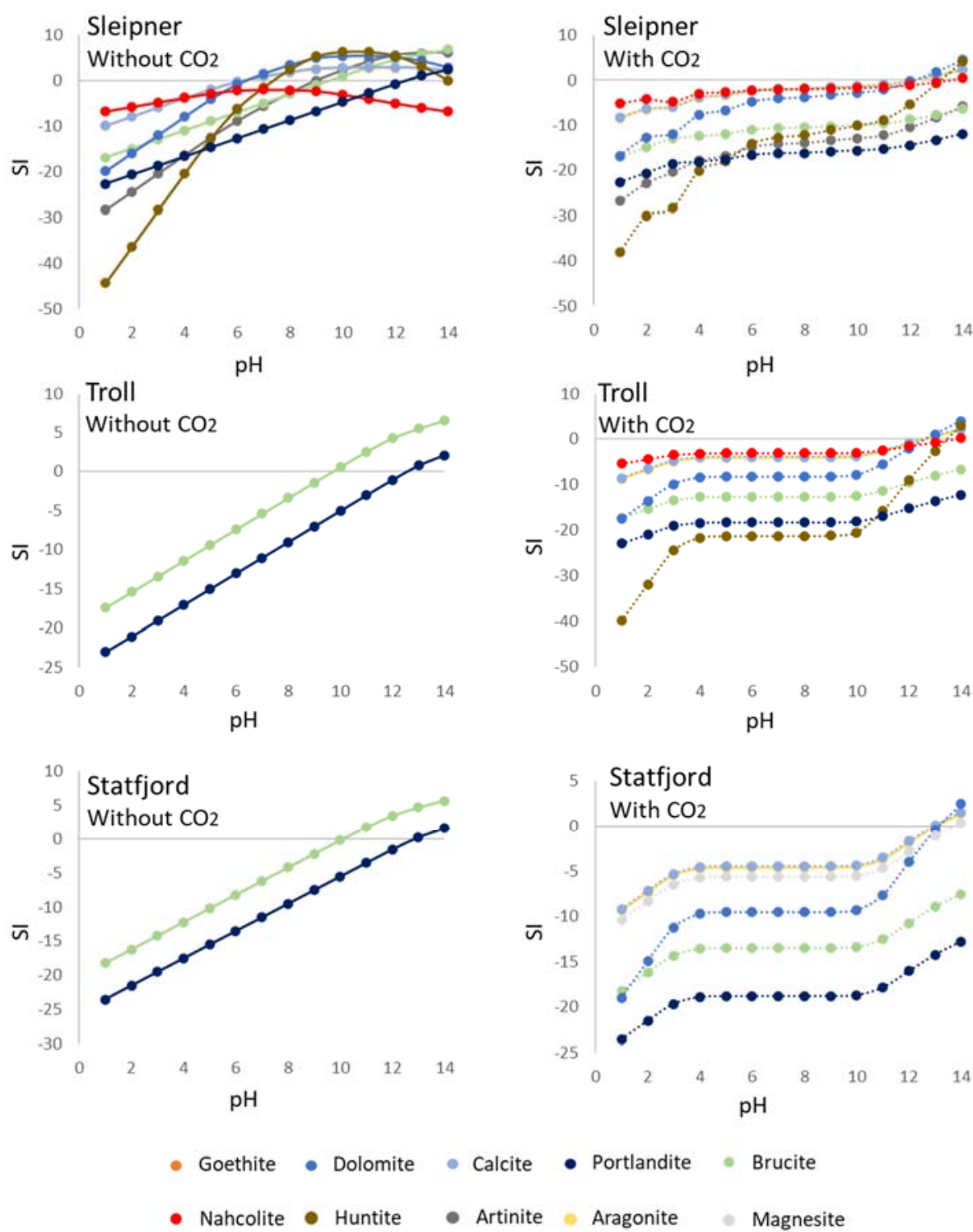

Figure 3. Modelled saturation indices (SI) for Sleipner, Troll and Statfjord formation waters at $23^{\circ} \mathrm{C}$ and $1 \mathrm{~atm}$ for different $\mathrm{pH}$ values, without (left) and with (right) additional $\mathrm{CO}_{2}$. The aragonite phase coincides with calcite.

Figures 2 and 3 show that without $\mathrm{CO}_{2}$, brucite $\left(\mathrm{Mg}(\mathrm{OH})_{2}\right)$ and portlandite $\left(\mathrm{Ca}(\mathrm{OH})_{2}\right)$ are the main crystalline phases that precipitate at alkaline conditions for all reservoir brines except Gyda. For the Gyda formation water, the precipitation of brucite was not predicted by the modelling. Instead, calcite, dolomite and goethite should precipitate at alkaline conditions. There are also several additional phases that, according to the modelling, are expected to precipitate from Sleipner without $\mathrm{CO}_{2}$; these are huntite $\left(\mathrm{Mg}_{3} \mathrm{Ca}\left(\mathrm{CO}_{3}\right)_{4}\right)$ and artinite $\left(\mathrm{Mg}_{2}\left(\mathrm{CO}_{3}\right)(\mathrm{OH})_{2} \cdot 3 \mathrm{H}_{2} \mathrm{O}\right)$.

Portlandite is formed by a reaction between calcium and hydroxide ions; see reaction (3) [31]. When adding $\mathrm{CO}_{2}$ to the initial solution, an increase in the carbonate ion concentration promotes the precipitation of calcium carbonate $\left(\mathrm{CaCO}_{3}\right)$ according to reaction (4) [16].

$$
\begin{gathered}
\mathrm{Ca}^{2+}+2 \mathrm{OH}^{-} \rightarrow \mathrm{Ca}(\mathrm{OH})_{2} \\
\mathrm{Ca}^{2+}+\mathrm{HCO}_{3}^{-}+\mathrm{OH}^{-} \rightarrow \mathrm{CaCO}_{3}+\mathrm{H}_{2} \mathrm{O}
\end{gathered}
$$

This means that adding gaseous $\mathrm{CO}_{2}$ to the formation water favours the precipitation of $\mathrm{CaCO}_{3}$ (as calcite or aragonite). The same behaviour is seen for brucite $\left(\mathrm{Mg}(\mathrm{OH})_{2}\right)$, 
which is formed by a reaction between magnesium and hydroxide ions; see reaction (5). When $\mathrm{CO}_{2}$ is present and dissolves in the solution, the precipitation of magnesite $\left(\mathrm{MgCO}_{3}\right)$ is favoured; see Reaction (6) [32].

$$
\begin{gathered}
\mathrm{Mg}^{2+}+2 \mathrm{OH}^{-} \rightarrow \mathrm{Mg}(\mathrm{OH})_{2} \\
\mathrm{Mg}^{2+}+\mathrm{HCO}_{3}^{-}+\mathrm{OH}^{-} \rightarrow \mathrm{MgCO}_{3}+\mathrm{H}_{2} \mathrm{O}
\end{gathered}
$$

The free magnesium ions from the solution can also react with free calcium ions to form dolomite $\left(\mathrm{CaMg}\left(\mathrm{CO}_{3}\right)_{2}\right)$ and huntite $\left(\mathrm{Mg}_{3} \mathrm{Ca}\left(\mathrm{CO}_{3}\right)_{4}\right)$; see reactions (7) and (8).

$$
\begin{aligned}
& \mathrm{Ca}^{2+}+\mathrm{Mg}^{2+}+2 \mathrm{HCO}_{3}^{-}+2 \mathrm{OH}^{-} \rightarrow \mathrm{CaMg}\left(\mathrm{CO}_{3}\right)_{2}+2 \mathrm{H}_{2} \mathrm{O} \\
& 3 \mathrm{Mg}^{2+}+\mathrm{Ca}^{2+}+4 \mathrm{HCO}_{3}^{-}+4 \mathrm{OH}^{-} \rightarrow \mathrm{Mg}_{3} \mathrm{Ca}\left(\mathrm{CO}_{3}\right)_{4}+4 \mathrm{H}_{2} \mathrm{O}
\end{aligned}
$$

The presence of a carbonate source in the Sleipner formation water leads to the formation of artinite; see reaction (9).

$$
2 \mathrm{Mg}^{2+}+\mathrm{CO}_{3}^{2-}+2 \mathrm{OH}^{-}+3 \mathrm{H}_{2} \mathrm{O} \rightarrow \mathrm{Mg}_{2}\left(\mathrm{CO}_{3}\right)(\mathrm{OH})_{2} \cdot 3 \mathrm{H}_{2} \mathrm{O}
$$

\subsection{Laboratory Experimental Results}

The Gyda, Smeaheia, Ekofisk, Sleipner, Troll and Statfjord formation waters were oversaturated at room temperature. The initial $\mathrm{pH}$ and conductivity measurements for all formation waters prior to electrochemical testing are shown in Table 2. The $\mathrm{pH}$ for all the brines ranged between 5.9 (for Gyda) and 6.9 (for Troll). The highest conductivity was also encountered in the Gyda brine while the lowest was in Statfjord, which is in line with the amount of the electrolyte present in the solution (Table 1) [33].

Table 2. Measured $\mathrm{pH}$, conductivity and calculated current density of the different formation waters tested.

\begin{tabular}{cccc}
\hline Formation Water & $\mathbf{p H}$ & Conductivity $(\mathbf{m S} / \mathbf{c m})$ & Current Density $\mathbf{( A / \mathbf { c m } ^ { 2 } )}$ \\
\hline Gyda & 5.9 & 213.0 & 0.2 \\
Smeaheia & 6.2 & 111.3 & 0.13 \\
Ekofisk & 6.7 & 107.8 & 0.13 \\
Sleipner & 6.6 & 133.1 & 0.10 \\
Troll & 6.9 & 0.001 & 0.05 \\
Statfjord & 6.7 & 0.0004 & 0.04 \\
\hline
\end{tabular}

The high conductivity of Gyda, Smeaheia, Ekofisk and Sleipner formation waters facilitate water-splitting processes via reactions (1) and (2) at the electrodes. The Troll and Statfjord formation waters had a significantly lower conductivity due to the lower salt content compared to Gyda, Smeaheia, Ekofisk and Sleipner (Table 1). The conductivity of the Troll and Statfjord formation waters is in the range of distilled water [34], meaning they will still conduct electric current, but the concentration of ions is not high enough for water splitting to occur to any great extent [33].

Images of graphite samples after cathodic polarization at $5 \mathrm{~V}$ for $30 \mathrm{~min}$ in different reservoir waters are presented in Figure 4 for experiments conducted without $\mathrm{CO}_{2}(\operatorname{Exp} 1)$ and with $\mathrm{CO}_{2}$ supply (Exp2). The weight of the precipitated material is presented in Table 3 . 


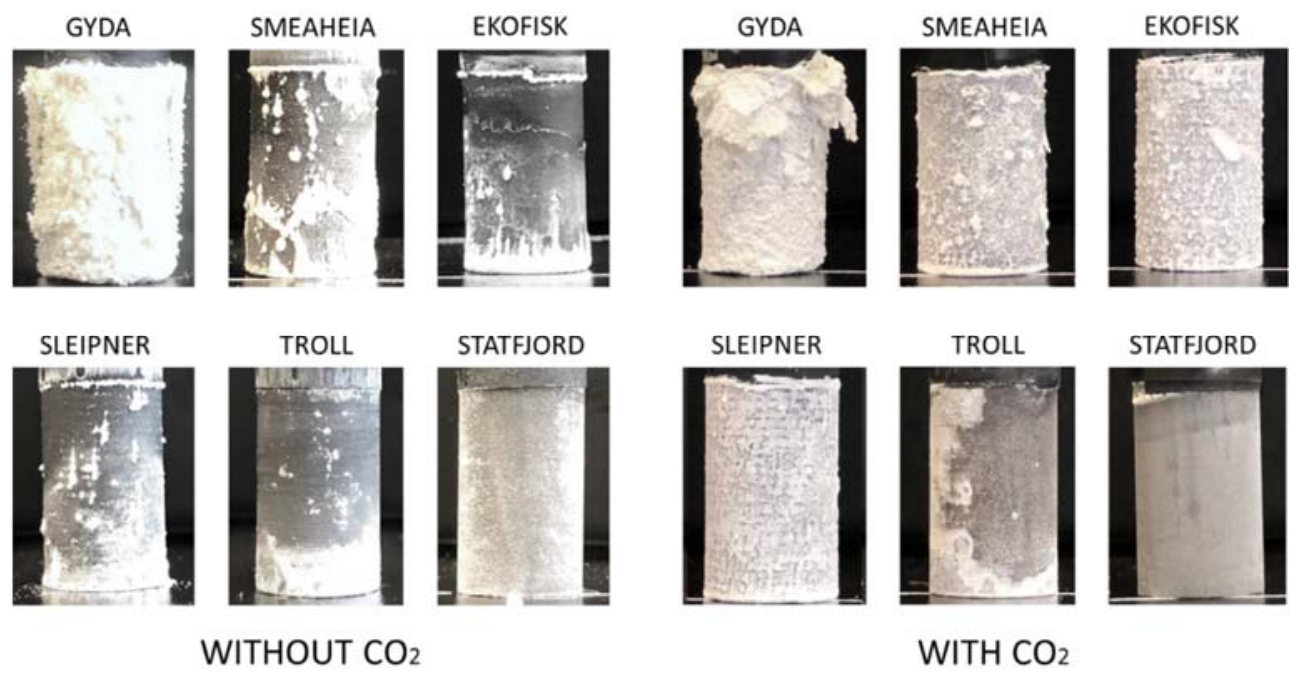

Figure 4. Images of graphite cathodes after polarization at $5 \mathrm{~V}$, for $30 \mathrm{~min}$ in different reservoir waters with (right) and without (left) additional $\mathrm{CO}_{2}$.

Table 3. Weight of the deposit (in grams) obtained from $200 \mathrm{~mL}$ of the different formation waters without and with $\mathrm{CO}_{2}$ supply.

\begin{tabular}{ccc}
\hline Formation Water & $\mathbf{W t}$ & $\mathbf{W t}_{\mathrm{CO} 2}$ \\
\hline Gyda & 0.17 & 0.18 \\
Smeaheia & 0.04 & 0.06 \\
Ekofisk & 0.04 & 0.07 \\
Sleipner & 0.05 & 0.06 \\
Troll & 0.02 & 0.02 \\
Statfjord & 0.01 & 0.01 \\
\hline
\end{tabular}

The formation-water composition had a significant impact on the amount of precipitated deposit on the electrode surfaces. Electro-deposition from Gyda formation water resulted in the greatest amount of mineral scale, with a thick layer all over the electrode surface. This can be explained by the high conductivity of the Gyda formation water (Table 2). Since conductivity is directly affected by salinity, formation waters with high conductivity generate more precipitate. This is because (i) the solution conducts sufficient electricity to facilitate water-splitting processes and (ii) the high concentration of salt contributes to fast oversaturation and thus efficient scale precipitation upon an electrochemically induced $\mathrm{pH}$ rise [33]. Electro-deposition from Smeaheia, Ekofisk and Sleipner formation waters resulted in significantly smaller amount of precipitate compared to Gyda. The conductivity of these formation waters was around half that of Gyda, which explains the lower amount of precipitate. The precipitate was also distributed differently compared to Gyda, which was also the case for Troll; most of the deposit was found on the lower part of the electrode. The sample exposed to Statfjord had an evenly distributed mineral deposit, but due to the low scaling ion content and conductivity of this formation water, the amount of precipitate was rather small.

In the presence of $\mathrm{CO}_{2}$, the deposit was distributed more homogeneously on the electrode surface compared to the experiment without $\mathrm{CO}_{2}$. It is likely that the $\mathrm{CO}_{2}$ gas contributed to a more even distribution of ions near the electrode surface. By introducing $\mathrm{CO}_{2}$ to the formation waters, most of the samples experienced an increase in the amount of deposited mineral (Gyda, Smeaheia, Ekofisk and Sleipner). Additionally, $\mathrm{CO}_{2}$ reacting with water forms carbonate $\left(\mathrm{CO}_{3}{ }^{2-}\right)$, bicarbonate $\left(\mathrm{HCO}_{3}{ }^{-}\right)$and hydrogen ions, which slightly increase the conductivity of the solution [35]. This might have contributed to the increase in the amount of precipitate. Another reason behind the increased amount of precipitate in the presence of $\mathrm{CO}_{2}$ may be the preferential formation of heavier carbonates over hydroxides. 
The XRD data presented in Figure 5 confirm that carbonates are more abundant in the precipitate deposited in the presence of $\mathrm{CO}_{2}$. The data for the Troll and Statfjord formation waters did not show any significant increase in precipitate when $\mathrm{CO}_{2}$ was purged through the solution.
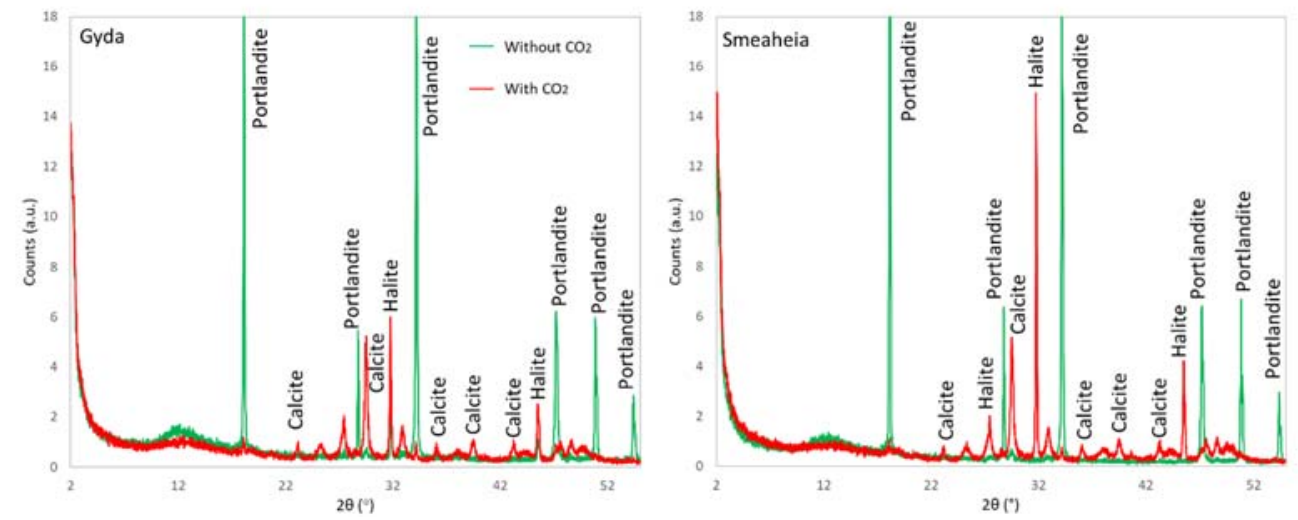

Figure 5. XRD patterns of material deposited at the cathode surface exposed to Gyda and Smeaheia formation water and polarized at $5 \mathrm{~V}$ for $30 \mathrm{~min}$. The green and red patterns refer to formation water without and with additional $\mathrm{CO}_{2}$, respectively.

Portlandite was the main crystalline phase present in the deposits from Gyda and Smeaheia formation waters when the solutions were not purged with $\mathrm{CO}_{2}$. When $\mathrm{CO}_{2}$ was present, the main crystalline phase was calcite, but halite was abundant in the precipitate. Gyda and Smeaheia formation waters were only slightly undersaturated with respect to $\mathrm{NaCl}$. It is therefore likely that $\mathrm{NaCl}$ will precipitate due to local oversaturation that could be caused by electrophoresis. Since the main crystalline phases present were both calciumbearing phases, the weight of the mineral deposit as a function of $\mathrm{CaCl}_{2}$ concentration for the different formation waters was plotted (see Figure 6).

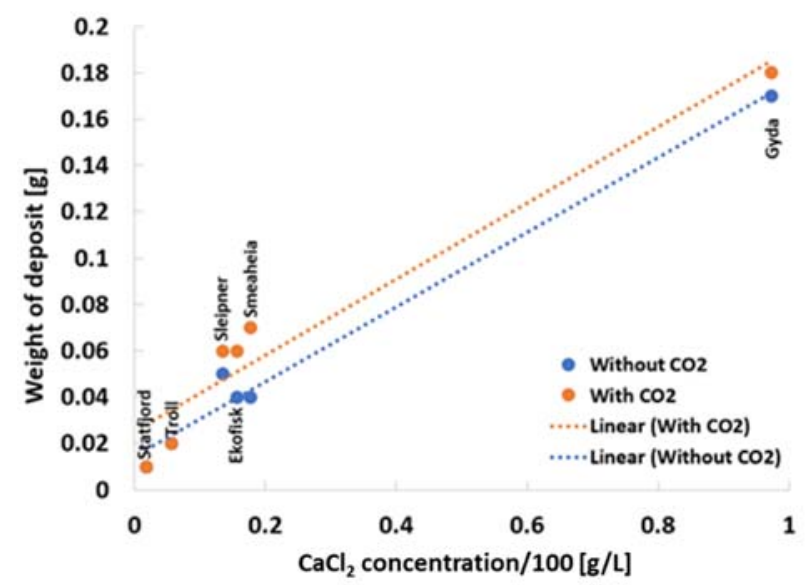

Figure 6. Relation between the concentration of calcium chloride in the solution (formation water) and the total weight of precipitate from $200 \mathrm{~mL}$ formation water in the absence and presence of $\mathrm{CO}_{2}$.

Figure 6 compares the amount of electrochemically precipitated material (after $30 \mathrm{~min}$ of polarization) at the cathode with the concentration of calcium-scaling ions present in the solution. It is seen that the amount of precipitate is proportional to the concentration of calcium ions. These results indicate that the factors of high significance during electrochemical deposition of scale barriers are (1) the conductivity and (2) the calcium concentration of the formation water or scaling solution. 


\section{Discussion}

For the electrochemical experiments, all the formation waters tested resulted in a measurable amount of precipitate located at the cathode surface. The main mineral phase changed from portlandite to calcium carbonate when $\mathrm{CO}_{2}$ was added to the system, and this was reflected both in the numerical simulations and in the XRD data. However, there are two major differences between the precipitating phases suggested by numerical simulations and the phases precipitated in the electrochemical experiments: (1) Numerical simulations for Gyda formation water (Figure 2) indicated that goethite $(\mathrm{FeOOH})$ would precipitate at a $\mathrm{pH}$ above 5. The XRD results (see Figure 5) reveal no iron-bearing phases in the scale deposit on the cathode. There are two reasons why goethite may be absent in the precipitate at the electrode surface: (i) the $\mathrm{pH}$ of the Gyda formation water was 5.9 and according to simulations goethite starts to precipitate at a $\mathrm{pH}$ as low as 4 . This suggests that at the initial $\mathrm{pH}$ of Gyda, iron could have already precipitated to a large extent, and (ii) the amount of iron present in the solution was rather small and thus the goethite precipitate might have been too small to be detected by XRD. (2) Another important discrepancy between the modelling and experimental results is the presence of magnesium minerals (brucite, magnesite and dolomite) seen in the modelling results. The XRD results did not show any traces of magnesium-bearing minerals in the precipitate obtained from the electro-deposition experiment of the Gyda and Smeaheia formation waters.

Lei et al. [36] studied the precipitation sequence of solids in electrochemically induced deposition from waste waters. They concluded that all ions precipitate simultaneously and not in a sequence. Nevertheless, the amount of deposited ions can be regulated by current density. This provides a possibility for the selective precipitation of different compounds by varying the current density [36]. Such a behaviour could explain the differences observed between the laboratory results and the numerical results where the electric field effect is not considered. The current-density effect could be a primary reason explaining the absence of brucite, or any magnesium-bearing compound, despite the presence of magnesium ions in the studied formation waters. It has been shown by Zeppenfeld [37] that the rate of magnesium electro-deposition in the form of brucite is strongly dependent on current density, whereby the deposition increases with current density. It has also been previously shown that brucite precipitation is sensitive to the magnesium and hydroxide concentration ratio. Small concentration ratios of $\mathrm{Mg}^{2+} / \mathrm{OH}^{-}$were found to promote the concentration of $\mathrm{MgOH}^{+}$(aq.) species in the solution, which are responsible for catalysing brucite precipitation [38]. Thus, high magnesium concentrations will counterintuitively slow down the precipitation of brucite. In our experiments, the magnesium ion molar concentrations ranged between 2 and $84 \mathrm{mM}$ for Statfjord and Gyda brines, respectively. The concentration of $84 \mathrm{mM}$ is much higher compared to the magnesium ion concentrations studied by Zeppenfeld $(2-6 \mathrm{mM})$. It is thus likely that the high concentrations of magnesium ions in the Gyda and Smeaheia waters caused brucite deposition to be further inhibited. Moreover, the concentrations of calcium ions were much higher than the concentrations of magnesium ions for all the formation waters studied here, thus the amount of potentially precipitating brucite might have been negligible compared to the amount of portlandite or calcite, which would put it below XRD detection limits.

\section{Implications for Possible Application of Mineral Electro-Deposition in Well Plugging}

In the context of P\&A our results suggest interesting application possibilities. Traditionally, wells are sealed mechanically by placing new cement plugs and today, Portland cement is the most common oil/gas well plugging material [6]. It consists mainly of portlandite $\left(\mathrm{Ca}(\mathrm{OH})_{2}\right)$ and calcium-silicate-hydrate, calcium-aluminate-hydrate and calcium-aluminoferrite-hydrate phases [39]. Portlandite and calcium silicate hydrate are the main cement hydration products contributing to the mechanical strength [40]. Our modelling and XRD results suggest that in a system without $\mathrm{CO}_{2}$, portlandite is the main mineral phase deposited from the tested formation water under the applied electric fields (Figures 3 and 5). 
When $\mathrm{CO}_{2}$ was injected to the system, portlandite was absent and instead calcite was the primary mineral phase (Figures 3 and 5) precipitating at the electrode surface. Similar carbonation processes are encountered in wellbore cement when exposed to $\mathrm{CO}_{2}$-saturated brine as shown by many laboratory, modelling and field studies ([41] and references therein). Portlandite and calcium silicate hydrates are dissolved upon carbonation and calcite is precipitated, whereby the porosity and permeability of the material decrease [42]. The carbonation of portlandite contributes to a volume increase of $>20 \%$, which in turn contributes to filling leakage pathways and decreasing porosity and permeability in general [41]. Whether or not the electro-deposition of portlandite or calcium carbonate can be utilized for well plugging will be dependent on the resulting mechanical properties, the permeability of the electro-deposited material as well as the practicalities related to designing tools for electrochemical well intervention.

\section{Conclusions}

In this paper, we showed how mineral scale deposition from different formation waters can be enhanced upon the cathodic polarization of electroconductive surfaces. The driving force for scale-deposition acceleration is the increase of local $\mathrm{pH}$ near the cathode due to water electrolysis. The growth of the scale deposit was found to be highly dependent on the formation-water composition. Formation waters with a high concentration of $\mathrm{Ca}$ ions and a high conductivity yielded more precipitate. The amount of precipitated material was proportional to the amount of calcium dissolved in the formation water. The electrodeposition from Gyda formation water was most efficient due to its high concentration of calcium-scaling ions and conductivity. Using the initial compositions of the formation waters, portlandite was the main precipitated phase. However, when adding $\mathrm{CO}_{2}$ gas to the solutions, the main precipitated phase changed to calcite (calcium carbonate). Despite the high concentrations of magnesium ions in the formation waters, magnesium-bearing mineral phases were not found in the electro-deposited material.

In future work, the next conclusive step is the investigation of ionic exchange and surface complexation between the formation water and the reservoir rock (e.g., Tetteh et al., 2022) [43]. Furthermore, the functionality of the method must be tested in a real-case scenario and the efficiency compared to conventional P\&A methods must be evaluated.

Supplementary Materials: The following supporting information can be downloaded at: https:/ / www.mdpi.com/article/10.3390/en15020542/s1. Table S1: Main mineral reaction equations, stability constants (log_k) and enthalpies (delta_h) at $25{ }^{\circ} \mathrm{C}$ reported in the wateq4f.dat thermodynamic data file.

Author Contributions: Conceptualization, M.T., K.M.G., B.U.E. and L.E.; methodology, M.T., K.M.G., B.U.E. and L.E.; software, B.U.E. and M.H.B.; validation, K.M.G., B.U.E., M.H.B. and L.E.; formal analysis, K.M.G., B.U.E., M.H.B. and L.E.; investigation, B.U.E. and M.H.B.; resources, M.T. and K.M.G.; data curation, B.U.E.; writing-original draft preparation, K.M.G., B.U.E., M.H.B. and L.E.; writing-review and editing, K.M.G., B.U.E., M.H.B. and L.E.; supervision, K.M.G.; project administration, K.M.G. and M.T.; funding acquisition, M.T. All authors have read and agreed to the published version of the manuscript.

Funding: This research was funded by The Norwegian Research Council in the form of grant number 285568 "Well fossilization for P\&A".

Institutional Review Board Statement: Not applicable.

Informed Consent Statement: Not applicable.

Acknowledgments: The authors thankfully acknowledge the financial support from the strategic SINTEF Industry project number 102021203 "Electrophoretic cleaning and friction reduction for applications in drilling and well construction".

Conflicts of Interest: The authors declare no conflict of interest. 


\section{References}

1. Lavrov, A.; Torsæter, M. Physics and Mechanics of Primary Well Cementing; Springer: Berlin/Heidelberg, Germany, 2016.

2. Mainguy, M.; Longuemare, P.; Audibert, A.; Lécolier, E. Analyzing the risk of well plug failure after abandonment. Oil Gas Sci. Technol. Rev. De L'ifp. 2007, 6, 311-324. [CrossRef]

3. Aas, B.; Sørbø, J.; Stokka, S.; Saasen, A.; Statoil, R.G.; Lunde, Ø.; Phillips, C.; Vrålstad, T. Cement Placement with Tubing Left in Hole During Plug and Abandonment Operations. In IADC/SPE Drilling Conf. And Exhibition; OnePetro: Fort Worth, TX, USA, 2016.

4. Achang, M.; Yanyao, L.; Radonjic, M. A review of past, present, and future technologies for permanent plugging and abandonment of wellbores and restoration of subsurface geologic barriers. Environ. Eng. Sci. 2020, 37, 395-408. [CrossRef]

5. Aguilar, P.; Johnson, C.R.; Salazar, J.; Bogaerts, M. Plug and Abandonment Solution for Oilfield Decommissioning in the North Sea. In Proceedings of the SPE Bergen One Day Seminar, Bergen, Norway, 20 April 2016.

6. Vrålstad, T.; Saasen, A.; Fjær, E.; Øia, T.; Ytrehus, J.D.; Khalifeh, M. Plug \& abandonment of offshore wells: Ensuring long-term well integrity and cost-efficiency. J. Pet. Sci. Eng. 2019, 173, 478-491.

7. Khalifeh, M.; Saasen, A. Introduction to permanent plug and abandonment of wells. Springer Nat. 2020, 12, 273.

8. Gabrielli, C.; Keddam, M.; Khalil, A.; Rosset, R.; Zidoune, M. Study of calcium carbonate scales by electrochemical impedance spectroscopy. Electrochim. Acta 1997, 42, 1207-1218. [CrossRef]

9. Thyne, G.; Brady, P. Evaluation of formation water chemistry and scale prediction: Bakken Shale. Appl. Geochem. 2016, 75, 107-113. [CrossRef]

10. Zavala, J.A.P.; Mackay, E.J.; Vazquez, O.; Boak, L.S.; Singleton, M.A.; Ross, G. The Cost and Value of Field, Laboratory, and Simulation Data for Validating Scale Inhibitor Treatment Models. In Proceedings of the SPE International Oilfield Scale Conference, Aberdeen, UK, 28-29 May 2008.

11. Chen, T.; Wang, Q.; Chang, F. $\mathrm{CaCO}_{3}$ Scale Risk Assessment-Thermodynamics vs Kinetics. In Proceedings of the CORROSION, Vancouver, BC, Canada, 6-10 March 2016.

12. Fink, J. Petroleum Engineer's Guide to Oil Field Chemicals and Fluids. Gulf Professional Publishing: Cambridge, MA, USA, 2021.

13. Gupta, K.H.; Roy, S. Geothermal Energy: An Alternative Resource for the 21st Century; Elsevier: Amsterdam, The Netherlands, 2006.

14. Hilbertz, W. Electrodeposition of minerals in sea water: Experiments and applications. IEEE J. Ocean. Eng. 1979, 4, 94-113. [CrossRef]

15. MacAdam, J.; Parsons, S.A. Calcium carbonate scale formation and control. Rev. Environ. Sci. Bio. Technol. 2004, 3, 159-169. [CrossRef]

16. Edvardsen, L.; Gawel, K.; Wenner, S.; Gawel, B.; Torsæter, M. Electrochemical enhancement and inhibition of calcium carbonate deposition. J. Environ. Chem. Eng. 2020, 8, 104239. [CrossRef]

17. Edvardsen, L.; Grandcolas, M.; Lædre, S.; Yang, J.; Lange, T.; Bjørge, R.; Gawel, K. Conductive epoxy/carbon nanofiber coatings for scale control. Surf. Coat. Technol. 2021, 425, 127694. [CrossRef]

18. Persat, A.; Suss, M.E.; Santiago, J.G. Basic principles of electrolyte chemistry for microfluidic electrokinetics. Part II: Coupling between ion mobility, electrolysis, and acid-base equilibria. Lab. A Chip. 2009, 9, 2454-2469. [CrossRef]

19. Hu, Y.; Mackay, E. Modeling of geochemical reactions occurring in the Gyda field under cold-seawater injection on the basis of produced-water-chemistry data and implications for scale management. SPE Prod. Oper. 2017, 32, 449-468. [CrossRef]

20. Ottemöller, L.; Nielsen, H.H.; Atakan, K.; Braunmiller, J.; Havskov, J. The 7 May 2001 induced seismic event in the Ekofisk oil field, North Sea. J. Geophys. Res. Solid Earth 2005, 110, B10301. [CrossRef]

21. Schwall, G.; Denney, C. Subsidence Induced Casing Deformation Mechanisms in the Ekofisk field. In Proceedings of the Rock Mechanics in Petroleum Engineering, Delft, The Netherlands, 29-31 August 1994.

22. Eiken, O.; Ringrose, P.; Hermanrud, C.; Nazarian, B.; Torp, T.A.; Høier, L. Lessons learned from 14 years of CCS operations: Sleipner, In Salah and Snøhvit. Energy Procedia 2011, 4, 5541-5548. [CrossRef]

23. Wu, L.; Thorsen, R.; Ottesen, S.; Meneguolo, R.; Hartvedt, K.; Ringrose, P.; Nazarian, B. Significance of fault seal in assessing $\mathrm{CO}_{2}$ storage capacity and containment risks-an example from the Horda Platform, northern North Sea. Pet. Geosci. 2021, 27, 102. [CrossRef]

24. Warren, A.E.; Smalley, C.; Howarth, R. Part 4: Compositional variations of North Sea formation waters. Geol. Soc. Lond. Mem. 1994, 15, 119-208. [CrossRef]

25. Parkhurst, L.D.; Appelo, C. Description of Input and Examples for PHREEQC Version 3: A Computer Program for Speciation, BatchReaction, One-Dimensional Transport, and Inverse Geochemical Calculations; U.S. Geological Survey: CA, USA, 2013.

26. Ball, W.J.; Nordstrom, D.K. User's Manual for Wateo4f, With Revised Thermodynamic Data Base and Test Cases for Calculating Speciation of Major, Trace, and Redox Elements in Natural Waters; U.S. Geological Survey: CA, USA, 1991.

27. Lu, P.; Zhang, G.; Apps, J.; Zhu, C. Comparison of thermodynamic data files for PHREEQC. Earth-Sci. Rev. 2021, 225, 103888. [CrossRef]

28. Gundogan, M.O.E.; Todd, A. Comparison of numerical codes for geochemical modelling of CO2 storage in target sandstone reservoirs. Chem. Eng. Res. Des. 2011, 89, 1805-1816. [CrossRef]

29. Metoki, N.; Sadman, K.; Shull, K.; Eliaz, N.; Mandler, D. Electro-assisted deposition of calcium phosphate on self-assembled monolayers. Electrochim. Acta 2016, 206, 400-408. [CrossRef] 
30. Kinn, S.F.; Pettersen, K.; Ramstad, F.; Rasmussen, H.; Hansen, T.H.; Goldsmith, J. PL 205 Licence Group Well 32/4-1. Final Well Report. 1998. Available online: https://factpages.npd.no/pbl/wellbore_documents/2918_32_4_1_COMPLETION_REPORT_ AND_COMPLETION_LOG.pdf. (accessed on 20 August 2021).

31. Ellis, L.D.; Badel, A.F.; Chiang, M.L.; Park, R.J.-Y.; Chiang, Y.-M. Toward electrochemical synthesis of cement-An electrolyzerbased process for decarbonating $\mathrm{CaCO}_{3}$ while producing useful gas streams. Proc. Natl. Acad. Sci. USA 2020, 117, 12584-12591. [CrossRef]

32. Schaef, H.T.; Windisch Jr, C.; McGrail, B.P.; Martin, P.F.; Rosso, K.M. Brucite $\left[\mathrm{Mg}\left(\mathrm{OH}_{2}\right)\right]$ carbonation in wet supercritical CO ${ }_{2}$ : An in situ high pressure X-ray diffraction study. Geochim. Cosmochim. Acta 2011, 75, 7458-7471. [CrossRef]

33. Helbæk, M.; Kjelstrup, S. Fysikalsk Kjemi. Fagbokforlaget Vigmostad Bjørke AS 2006, 2, 796.

34. Nihlgård, B.; Rosborg, I.; Ferrante, M. Mineral Composition of Drinking Water and Daily Uptake. In Drinking Water Minerals and Mineral Balance; Springer: Cham, Switzerland, 2019; pp. 25-32.

35. Fleury, M.; Deschamps, $\mathrm{H}$. Electrical conductivity and viscosity of aqueous $\mathrm{NaCl}$ solutions with dissolved $\mathrm{CO}_{2}$. J. Chem. Eng. Data 2008, 53, 505-2509. [CrossRef]

36. Lei, Y.; Remmers, C.J.; Saakes, M.; van der Weijden, D.R.; Buisman, J.C. Is there a precipitation sequence in municipal wastewater induced by electrolysis? Environ. Sci. Technol. 2018, 52, 8399-8407. [CrossRef]

37. Zeppenfeld, K. Electrochemical removal of calcium and magnesium ions from aqueous solutions. Desalination 2011, 277, 99-105. [CrossRef]

38. Pokrovsky, S.O.; Schott, J. Experimental study of brucite dissolution and precipitation in aqueous solutions: Surface speciation and chemical affinity control. Geochim. Cosmochim. Acta 2004, 68, 31-45. [CrossRef]

39. Wesselsky, A.; Jensen, O.M. Synthesis of pure Portland cement phases. Cem. Concr. Res. 2009, 39, 973-980. [CrossRef]

40. Kunther, W.; Ferreiro, S.; Skibsted, J. Influence of the Ca/Si ratio on the compressive strength of cementitious calcium-silicatehydrate binders. J. Mater. Chem. A 2017, 5, 17401-17412. [CrossRef]

41. Xiao, T.; McPherson, B.; Bordelon, A.; Viswanathan, H.; Dai, Z.; Tian, H.; Esser, R.; Jia, W.; Carey, W. Quantification of CO 2 -cementrock interactions at the well-caprock-reservoir interface and implications for geological $\mathrm{CO}_{2}$ storage. Int. J. Greenh. Gas Control 2017, 63, 126-140. [CrossRef]

42. Kutchko, B.G.; Strazisar, B.R.; Dzombak, D.A.; Lowry, G.V.; Thaulow, N. Degradation of well cement by $\mathrm{CO}_{2}$ under geologic sequestration conditions. Environ. Sci. Technol. 2007, 41, 4787-4792. [CrossRef]

43. Tetteh, J.T.; Pham, A.; Peltier, E.; Hutchison, J.M.; Ghahfarokhi, R.B. Predicting the electrokinetic properties on an outcrop and reservoir composite carbonate surfaces in modified salinity brines using extended surface complexation models. Fuel 2022, 309, 122078. [CrossRef] 